\title{
ЕКЗИСТЕНЦІАЛЬНА РЕФЛЕКСІЯ ЯК ДІАГНОСТИЧНИЙ КОНСТРУКТ: ВЕРИФІКАЦІЯ ОСНОВНИХ ПОЛОЖЕНЬ
}

\section{Репецъка Анжела Василівна}

Старший викладач кафедри психології Запорізького Національного технічного університету, м. Запоріжжя (Украӥна)

\begin{abstract}
Аннотация. Об'єкт нашого дослідження: особистісне самовизначення студентів. Предмет дослідження: екзистенціальна рефлексія. Мета дослідження: емпірично обтрунтувати концептуальну модель екзистенціальної рефлексї, виявити ї̈ місце і роль в процесі особистісного самовизначення. Екзистенціальна рефлексія - ие механізм структурування $і$ трансформації екзистенціального досвіду особистості. Екзистенціальна рефлексія відіграє важливу роль в роботі механізму екзистенціального смислоутворення і смислової динаміки.

Об’єктом екзистенціальної рефлексії $\epsilon$ екзистенціальний досвід. екзистенціального досвіду є три джерела смислу $i$ функціонує, відповідно, три механізми смислоутворення: 1) в основі мотиваџійного механізму лежить смисл життя; 2) в основі диспозииійного механізму - самоставлення особистості; 3) в основі атрибутивного механізму - Яконцепція як сукупність якостей і особливостей особистості. Внесок кожного джерела вивчався нами за допомогою відповідних психодіагностичних методик: 1. Психосемантична діагностика прихованої мотивації (І.Л. Соломін). 2. Методика дослідження самоставлення (С.Р. Пантилєєв). 3. Опитувальник смисложиттєвої кризи (К.В. Карпінський). 4. Методика визначення домінуючого стану (повний варіант, Л.В. Куликов).

В ході емпіричної верифікації концептуальної моделі екзистенціальної рефлексї було продіагностовано 271 студента різних вишів, різних спеціальностей і курсів віком від 17 до 22 років. Результат екзистенціально-рефлексивної роботи оцінювався через особливості структури екзистенціального досвіду, представленої семантичним простором з 15 базових понять - маркерів екзистениій.

За результатами дослідження було виявлено, щзо для більшості досліджуваних не $\epsilon$ актуальним процес пошуку себе (процес самовизначення) і формування результату цуього процесу готовності до самореалізації. На тлі ичих процесів екзистенціальна робота особистості та ї̈ складова - екзистенціальна рефлексія - в цілому має спонтанний і латентний характер.
\end{abstract}


DOI (Issue): https://doi.org/10.31108/2018vol13iss3

№ 3 (13) 2018

Наша основна теза: екзистенціальні смислоутворення, смислоусвідомлення, смислопобудова відіграють ключову роль в процесі особистісного самовизначення.

Ключевъе слова: особистісне самовизначення, екзистенціальна робота особистості, екзистенціальна рефлексія, екзистенціальний досвід, смисл життя, самоставлення, емпірична верифікачія, психосемантичний простір.

Постановка проблеми. Кожній людині притаманне прагнення знайти і реалізувати себе, стати такою, якою вона повинна і може стати. Вся історія і культура людства рясніє різними прикладами та настановами про те, як знайти себе, самовизначившись в тому, чого реально хочеш і що можеш; рекомендаціями про те, як правильно ставитися до власних досягнень, успіхів і втрат, до перемог і поразок. Невдачі в такому пошуку супроводжуються втратою відчуття радості, повноти власного життя i, навіть, iї смислу, а успіхи - навпроти - їх набуттям. Який психологічний концепт сьогодні найбільш повно і точно відображає складний і багатоаспектний процес такого пошуку? Ми вважаємо, що це особистісне самовизначення. Додамо, що пошук особистістю себе і зміни уявлення про себе, уявлення про свої життєві ставлення, про своє місце і роль у цих ставленнях постійно супроводжується спробами знайти певні точки опори, підстави свого буття. У свою чергу, пошук, знаходження і ствердження людиною підстав свого буття, точок опори являє собою складну психологічну роботу впродовж усього життя, або екзистенціальну роботу особистості. Найбільш цілісним результатом екзистенціальної роботи особистості є набуття нею смислу життя - узагальненого мотиву життє- діяльності, який успішно виконує свою спонукальну, спрямовуючу і смислоутворюючу функцію.

Постановка завдань. Яке місце і роль екзистенціальної роботи на різних етапах i стадіях особистісного самовизначення? Як співвідносяться між собою переживальна i рефлексивна форми екзистенціальної роботи? Як відбувається осмислення і переосмислення особистістю свого екзистенціального досвіду в процесі особистісного самовизначення? Ці питання узагальнюються в основні питання проблеми - у чому сутність екзистенціальної рефлексії, яке іiї місце та роль в процесі особистісного самовизначення, яким чином та за допомогою яких діагностичних засобів можливо оцінити рівень ії розвитку?

Мета статті - запропонувати концептуальну модель екзистенціальної рефлексії, індикатори для іiї емпіричної верифікації та діагностичної оцінки в контексті процесу особистісного самовизначення студентів (в старшому юнацькому віці).

\section{Аналіз останніх досліджень і публі-} кацій. Найбільш перспективно і продуктивно, на наш погляд, вивчати екзистенціальну рефлексію, особливо в емпіричному плані, - в контексті процесу особистісного самовизначення, який розуміється як осмислення і пере- 
осмислення особистістю ступеня своєї готовності до самореалізації [6]. Особистісне самовизначення має чітко виражений екзистенціальний аспект. Зазначимо, що власне особистісне самовизначення починається 3 того, що смисл життя як узагальнений мотив життєдіяльності перестає виконувати свою спонукальну, спрямовуючу і смислоутворюючу функцію. I, навпаки, завершується процес успішного особистісного самовизначення формуванням нового чинного узагальненого мотиву життєдіяльності або смислу життя.

Смисл життя, згідно сучасним уявленням, є стрижневим утворенням смислової сфери особистості і ведучою інстанцією мотиваційної регуляції іiї індивідуальної життєдіяльності, яке лежить за межами індивідуальної свідомості, і для усвідомлення якого від особистості потрібна спеціальна рефлексивна робота, спрямована на свій внутрішній світ або життєвий шлях [2]. У цій рефлексивній роботі, на наш погляд, основну роль відіграє саме екзистенціальна рефлексія.

Вперше поняття «екзистенціальна рефлексія» введено I. М. Семеновим в 1990 р. в результаті диференціації різних типів рефлексії: інтелектуальної, особистісної, комунікативної, кооперативної, культуральної [11].

М. Ю. Двоєглазова, І. М. Семенов визначають екзистенціальну рефлексію як інтегральне утворення, яке складається із сукупності інтелектуальної, кооперативної, комунікативної, особистісної та регулятивної рефлек- сій. Актуалізуючись в проблемно-конфліктних ситуаціях, екзистенціальна рефлексія призводить до радикальної зміни «Я» як цілого. Після подолання проблем, екзистенціальна рефлексія знову диференціюється на попередні їй типи рефлексивних процесів, але ці процеси вже протікають на основі функціональної структури особистості [1].

Виклад основного матеріалу. Ми вважаємо, що екзистенціальна рефлексія - це процес вилучення, добування екзистенціального смислу 3 відповідного (екзистенціального) досвіду особистості. На нашу думку, екзистенціальна рефлексія відіграє ключову роль у процесах смислоутворення, смислоусвідомлення і смислопобудови, а феноменологічно це проявляється як пошук, знаходження i розробка екзистенціальних утворень різного ступеня спільності, аж до інтегрального утворення - смислу життя особистості [7].

Саме за рахунок екзистенціальної рефлексії здійснюється упорядкування і структурування екзистенціального досвіду, його використання в процесі регуляції життєдіяльності особистості.

Згідно положень, які розвиваються нами, екзистенціально-рефлексивний процес виникає у відповідь на ситуацію екзистенціального утруднення. В свою чергу, екзистенціальні труднощі, не отримавши належного вирішення, призводять до екзистенціальної або смисложиттєвої (за К. В. Карпінським) кризи. 
Залежно від етіології, можуть бути диференційовані три різновиди смисложиттєвої кризи: криза безглуздості, криза смислоутрати і криза неоптимального смислу життя [2].

Криза безглуздості настає через відсутність смислу в житті і неможливість його відшукати. Криза смислоутрати породжувана втратою смислу життя в критичній ситуації i неможливістю його відновити. Криза неоптимального смислу життя в цілому може бути охарактеризована як самореалізаційна криза, оскільки в іï основі лежить протиріччя між прагненням особистості реалізувати смисл життя і неможливістю зробити це 3 належною продуктивністю [2].

Екзистенціальна або смисложиттєва криза - це завжди складова більш широкої, життєвої кризи. Життєва криза або кардинальна життєва ситуація - не просто проблемноконфліктна ситуація, а ситуація порушення ціннісно-смислової єдності особистості. Порушення такої єдності виражається, насамперед, у зміні характеру або якості (рівня) життєвих ставлень особистості, іiї самореалізації. Підстави буття особистості, основні координати i виміри іiі існування, функціонування і розвитку втрачають свою цінність. Це і є екзистенціальна або смисложиттєва криза, або криза основ існування особистості.

Подолання кардинальної життєвої ситуації відбувається шляхом знаходження особистістю своєї ціннісно-смислової єдності та феноменологічно проявляється через зміну уявлення про себе (образу Я) і ставлення до себе (смислу Я), а також знаходження нових основ існування, форм і способів самоздійснення. Згідно наших положень, це і $є$ процес особистісного самовизначення або формування готовності до самореалізації.

Особистісне самовизначення неможливе без екзистенціальної рефлексії, яка забезпечує всі види екзистенціально-смислових процесів: екзистенціальне смислоутворення, екзистенціальне смислоусвідомлення і екзистенціальну смислопобудову. Феноменологічно це проявляється як пошук, знаходження і розробка екзистенціальних утворень різного ступеня спільності, аж до інтегрального утворення смислу життя особистості.

Об’єктом екзистенціальної рефлексії $\epsilon$ екзистенціальний досвід, у зміст якого входять і джерела екзистенціального смислу. Згідно 3 положеннями, що розвиваємо ми, зазначимо, що в основі мотиваційного джерела екзистенціальних смислів особистості i, відповідно, механізму екзистенціального смислоутворення, лежить смисл життя як узагальнений мотив життєдіяльності; в основі диспозиційного джерела - самоставлення (смисл Я); в основі атрибутивного джерела і механізму екзистенціальних смислів особистості - Яконцепція як відображення якостей та здібностей особистості.

Екзистенціальний досвід можна розглядати як деякий семантичний простір, до якого входять і екзистенції - поняття і уявлення, які 
відіграють роль базових, вихідних підстав буття людини. На нашу думку, одна з найважливіших функцій екзистенціальної рефлексії полягає в осмисленні і переосмисленні місця і ролі екзистенцій в життєдіяльності особистості. Оцінити місце і роль екзистенцій в життедіяльності особистості можна через структуру семантичного простору. Саме такий підхід i був використаний в нашому дослідженні. При цьому, в структуру семантичного простору нами також включені індикатори, що характеризують особистісне самовизначення і самореалізацію особистості.

Представлені теоретичні положення дозволяють запропонувати концептуальну модель екзистенціальної рефлексії і систему індикаторів, що дозволяють провести її емпіричну верифікацію.

1. Семантичний простір містить екзистенції і маркери, що характеризують особливості особистісного самовизначення та самореалізації досліджуваних. Фактично, структура цього простору відображає результати роботи екзистенціальної рефлексії. Місце і роль продуктів (результатів) роботи екзистенціальної рефлексії у структурі та змісті готовності до самореалізації оцінювалися нами за допомогою методики «Психосемантична діагностика прихованої мотивації» (І. Л. Соломін) [12].

2. Особливості самоставлення - найбільш цілісний і інформативний показник успішності протікання процесу особистісного самовизначення, результатом якого є формування готовності до самореалізації. Готовність до самореалізації - це, в першу чергу, чітко виражений позитивний особистісний смисл Я, сформованість якого і відображається в особливостях самоставлення. Власне самореалізація спрямована на підтвердження і втілення цього смислу в діяльності і в реалізації життевих ставлень, послідовно обгрунтовується в наших роботах $[1 ; 5 ; 7]$. Цей показник оцінюється нами за допомогою методики дослідження самоставлення (С. Р. Пантилєєв) [5].

3. Екзистенціальна робота особистості особливо інтенсивно протікає при виникненні смисложиттєвої кризи. Саме якість екзистенціальної роботи, певне гармонійне поєднання iii рефлексивного та переживального аспектів - запорука продуктивного і успішного вирішення такої кризи.

3 точки зору феноменології, смисложиттєва криза - це процес інтенсивних і суб'єктивно тяжких переживань особистості, які пофарбовані глобальною незадоволеністю життям і обумовлені труднощами у визначенні та здійсненні смислу життя, у постановці життєвих цілей, у побудові життєвих прогнозів, планів і програм, у формуванні цілісної суб'єктивної картини індивідуального життєвого шляху, у прийнятті життєво важливих рішень, в оцінюванні результатів самореалізації та суб'єктивному контролі життя, у виробленні адекватного ставлення до минулого, сьогодення і майбутнього, а також до факту 
власної смертності [2].

Оцінити особливості смисложиттєвої кризи дозволяє спеціальний опитувальник К. В. Карпінського [3], який характеризує загальний функціональний рівень смислової регуляції життєвого шляху, а також рівень загальної свідомості життя, включаючи осмисленість минулого, сьогодення і майбутнього. Чим вищий показник смисложиттєвої кризи, тим сильніше, стійкіше і глибше людина переживає симптоми безглуздості. Опитувальник призначений для вивчення негативних аспектів суб'єктивних переживань і поведінки людини, що має проблеми з визначенням і практичним втіленням смислу життя. Він $є$ спеціалізованим інструментом для аналізу феноменології кризи безглуздості.

4. Смисложиттєва криза являє собою триваючий психічний стан, який виникає на основі нерозв'язних або нерозв'язаних суперечностей у пошуку та практичній реалізації особистістю смислу індивідуального життя. При цьому особистість відчуває цілий комплекс негативних почуттів: незадоволеності, невиконання, апатії, неспроможності, фрустрації і т. д. Методика визначення домінуючого стану (повний варіант, Л. В. Куликов [4]) визначає характеристики настроїв і деякі характеристики особистісного рівня психічних станів за допомогою суб'єктивних оцінок досліджуваного. Опитувальник призначений, головним чином, для діагностики відносно стійких (домінуючих) станів. Ця методика, на наш по- гляд, має важливі емпіричні індикатори, які прямо або побічно відображають хід процесу особистісного самовизначення, i презентує певні продукти цього процесу.

Тож, на першому етапі нашого емпіричного дослідження було продіагностовано 271 студента різних вишів, різних спеціальностей та курсів віком від 17 до 22 років. Відбір досліджуваних проводився випадковим чином за принципом добровільності участі.

Результати екзистенціально-рефлексивної роботи в процесі особистісного самовизначення знаходять своє відображення в 15 базових поняттях-маркерах, що утворюють семантичний простір досліджуваних. Результати оцінки понять за факторами ЦінністьАктивність-Потенція представлені в Таблиці 1 .

Найбільшу емоційну привабливість (цінність) мають такі маркери як Любов, Моє майбутнє. Ми припускаємо, що це відображає склад вибірки досліджуваних, в якій, в більшості своїй, представлені дівчата (69 \% від загальної кількості досліджуваних). Середні арифметичні за цими індикаторами рівні, що вказує на злитість, недиференційованість цих життєвих проявів у свідомості досліджуваних.

На другому місці знаходиться такий індикатор як «Бути собою». Цей індикатор вказує, скоріше за все, на актуальність для більшості досліджуваних процесу самостверждення, а не самовизначення. Це також може вказувати на консервативну прив'язаність до 
Таблиця 1.

Оцінка понять-маркерів по факторам за методикою «Психосемантична діагностика скритої мотивації» (І. Л. Соломін)

\begin{tabular}{|c|c|c|c|c|c|c|}
\hline \multirow{3}{*}{ Поняття-маркери } & \multicolumn{6}{|c|}{ Фактори } \\
\hline & \multicolumn{2}{|c|}{ Цінність } & \multicolumn{2}{|c|}{ Активність } & \multicolumn{2}{|c|}{ Потенція } \\
\hline & Середнє & $\begin{array}{l}\text { Станд. } \\
\text { відхил. }\end{array}$ & Середнє & $\begin{array}{l}\text { Станд. } \\
\text { відхил. }\end{array}$ & Середнє & $\begin{array}{l}\text { Станд. } \\
\text { відхил. }\end{array}$ \\
\hline 1. Успіх в житті & 5,67 & 0,47 & 4,83 & 0,90 & 5,17 & 0,69 \\
\hline 2. Бути собою & 5,83 & 0,37 & 4,17 & 0,90 & 4,83 & 0,37 \\
\hline 3. Знайти себе, своє місце в житті & 5,67 & 0,47 & 5,00 & 1,15 & 5,00 & 0,82 \\
\hline 4. Реалізувати себе & 5,67 & 0,47 & 5,00 & 1,15 & 5,17 & 0,69 \\
\hline 5. Моє минуле & 4,67 & 0,47 & 4,33 & 0,47 & 4,67 & 0,47 \\
\hline 6. Моє теперішнє & 5,00 & 0,00 & 4,33 & 0,75 & 5,00 & 0,00 \\
\hline 7. Моє майбутнє & 6,00 & 0,00 & 4,50 & 1,50 & 5,17 & 0,90 \\
\hline 8. Задоволеність життям & 5,00 & 0,00 & 4,33 & 0,75 & 4,67 & 0,47 \\
\hline 9. Свобода & 5,67 & 0,47 & 4,17 & 0,90 & 5,00 & 0,58 \\
\hline 10. Відповідальність & 4,83 & 0,37 & 4,67 & 0,47 & 4,50 & 0,50 \\
\hline 11. Самотність & 3,00 & 0,58 & 4,50 & 0,50 & 3,00 & 0,58 \\
\hline 12. Смисл життя & 5,33 & 0,47 & 4,50 & 0,96 & 4,50 & 0,50 \\
\hline 13. Любов & 6,00 & 0,00 & 4,50 & 1,61 & 5,33 & 0,75 \\
\hline 14. Я & 5,00 & 0,00 & 4,17 & 0,69 & 4,67 & 0,47 \\
\hline 15. Смерть & 2,17 & 0,37 & 5,50 & 0,50 & 3,33 & 0,75 \\
\hline Середні значення & 5,03 & & 4,57 & & 4,67 & \\
\hline Стандартні відхилення & 1,06 & & 0,36 & & 0,64 & \\
\hline
\end{tabular}

свого образу «Я» значної частини досліджуваних. Індикатори особистісного самовизначення, а саме - «Успіх в житті», «Знайти себе і своє місце в житті», «Реалізувати себе», «Свобода» - знаходяться на третьому місці. При цьому рівність середніх арифметичних за цими індикаторами також може вказувати на злитість, недиференційованість цих життєвих проявів у свідомості досліджуваних. Таким чином, процес особистісного самовизначення у наших досліджуваних, високоймовірно, ще не завершився, або протікає не зовсім успішно/непродуктивно.

Фактор «Активність» показує ступінь динамічності, мінливості процесів і явищ, зафіксованих в координатах заданого нами семантичного простору. На нашу думку, це саме ті показники, які на даному етапі життєвого шляху є предметом екзистенціальної рефлексії. Найбільші середні значення за цим фактором спостерігаються для маркерів «Смерть», а далі - «Реалізувати себе» та «Знайти себе і своє місце в житті».

Таким чином, ми припускаємо, що в цілому досліджувані знаходяться на початковій фазі особистісного самовизначення, а саме - наявної екзистенціальної кризи.

Фактор «Потенція (Сила)» вказує на 
ступінь впливу на людину життєвих проявів, зафіксованих в поняттях-маркерах. Найбільші середні арифметичні значення отримані для індикатору «Любов», далі слідують - «Успіх в житті», «Моє майбутнє», «Реалізувати себе». Основний індикатор процесу особистісного самовизначення - «Знайти себе і своє місце в житті» - має значимо меншу вагу. Така картина може вказувати на значний вплив на досліджуваних розповсюджених соціальних стереотипів.

Співставлення найбільш вагомих індикаторів за всіма трьома факторами дозволяє припустити, що процес особистісного самовизначення у досліджуваних носить ситуативний і спонтанний характер. «Пошук себе», а, відповідно, і подальша продуктивна і успішна самореалізація ще не зайняли відповідного місця у свідомості досліджуваних. Основні екзистенції також мало представлені у свідомості досліджуваних, що може вказувати на слабку, в цілому, їх екзистенціальнорефлексивну роботу.

Центральними поняттями, що характеризують процес і результат особистісного самовизначення, є маркери «Знайти себе і своє місце в житті», «Реалізувати себе», «Бути собою», «Я».

Хоча в цілому досліджувані усвідомлюють зв'язок між пошуком себе і свого місця в житті, реалізація себе и успіх в житті - це для них скоріше справа майбутнього, а не теперішнього. Слабо пов'язаний з індикаторами особистісного самовизначення, що вказані вище 3 маркером «Смисл життя». Тим не менш, власне процес особистісного самовизначення починається 3 втрати чинного смислу життя i закінчується здобуттям нового чинного смислу, що виконує спонукальну, смислоутворюючу і регулятивну функції. Показово те, що у наших досліджуваних в цілому «Смисл життя» досить близький до «Відповідальності» (нормована відстань 0,66). Це може вказувати на значний вплив соціальних стереотипів на смисл життя досліджуваних. Вони живуть під зовнішнім тиском, скоріш за все батьків.

Ще ближче в семантичному просторі «Смисл життя» знаходиться до такого маркера як «Задоволеність життям» (нормована відстань - 0,61). Це також може свідчити, що смисл життя наших досліджуваних знаходиться під впливом актуальних умов існування, i це їх взагалі задовольняє .

Задоволеність життям найбільш близька до таких маркерів як «Моє минуле» (нормована відстань - 0,32) i «Я» (нормована відстань - 0,46). Близько до цього і «Моє теперішнє» (нормована відстань - 0,52). Тобто, на цих досліджуваних сильно впливає минуле, їх образ «Я», перенесений 3 минулого в сьогодення, i в цілому їх це задовольняє. Це може свідчити про невиразність процесу особистісного самовизначення, який завжди пов'язаний зі зміною уявлення 
про себе, з переоцінкою свого минулого і певною привабливістю майбутнього.

Злитність теперішнього та майбутнього а також задоволеності собою може просто вказувати на відсутність у досліджуваних відповідного досвіду, який може бути осмислений i переосмислений за рахунок рефлексії, в тому числі і екзистенціальної.

Все вищезазначене наочно видно 3 дендрограми, представленої на Рисунку 1.

На відсутність активного процесу самовизначення вказує близькість понять «Я» та «Задоволеність життям» (нормативна відстань - 0,46). В цілому, досліджувані живуть в сьогоденні задоволені тим як вони живуть та поки що не вважають актуальною власну самореалізацію.

Важливим показником успішного особистісного самовизначення є такий маркер як «Свобода», який найближче розташований до маркера «Бути собою» (нормативна відстань 0,3). Далі розташовуються «Задоволеність життям» (нормативна відстань - 0,94) та «Моє минуле» (нормативна відстань - 1,17).

Таким чином, предметом екзистенціальної рефлексії досліджуваних, скоріше за все, $\epsilon$ «Я»-концепція досліджуваних і життєва ситуація, в якій вони перебувають. Найімовірніше, екзистенціальна рефлексія досліджуваних не зачіпає ключові аспекти особистісного самовизначення, а саме - пошук себе, і прагнення знайти себе і бути собою.

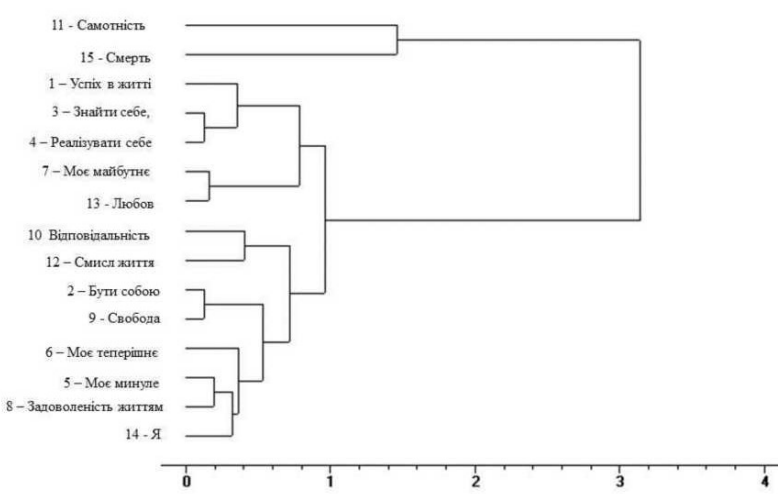

Рис. 1. Дендрограма семантичного простору понять-маркерів особистісного самовизначення досліджуваних.

Результати дослідження за методикою «Опитувальник смисложиттєвої кризи» представлено в Таблиці 2.

Чим для нас особливо цінний отриманий результат? Насамперед тим, що отримані нами вибіркові середнє значення і стандартне відхилення з високою статистичною достовірністю збігаються з відповідними показниками вибірки стандартизації тесту. Для чоловіків такі показники відповідно 225,4 і 35,69, а для жінок - 218,73 і 32,66. Це може вказувати, поперше, на високу релевантність тесту до досліджуваної нами реальності, а по-друге - на можливість коректного поділу вибірки на групи за ступенем вираженості смисложиттєвої кризи. За допомогою кластер-аналізу нами було отримано три кластери, в які увійшло відповідно 104, 72 та 95 досліджуваних.

Результати визначення домінуючого стану представлено в Таблиці 3.

Як видно з Таблиці 4, за шкалою «Активне-пасивне» ставлення до життєвої си- 
Табличя 2.

Результати за методикою «Опитувальник смисложиттєвої кризи» (К. В. Карпінський)

\begin{tabular}{|c|c|c|c|}
\hline $\begin{array}{c}\text { Шкала } \\
\text { методики }\end{array}$ & $\begin{array}{c}\text { Серед- } \\
\text { нє }\end{array}$ & $\begin{array}{c}\text { Станд. } \\
\text { помилка }\end{array}$ & $\begin{array}{c}\text { Станд. } \\
\text { відхилення }\end{array}$ \\
\hline СЖК & 225,2 & 2,3 & 37,1 \\
\hline
\end{tabular}

туації (АК), результати більшості досліджуваних знаходяться в межах тестової норми. Ця шкала несе важливу інформацію, тому що відображає ставлення досліджуваних до життєвої ситуації. Життєва ситуація - це взаємодія усвідомлених і неусвідомлених мотивів, можливостей особистості (здібностей і прихованих потенціалів) і життєвих умов (об'єктивні життєві події та їх суб'єктивне сприйняття і оцінка) (Л. Бурлачук, Н. Чепелєва та ін.). Лю- дина визначається по відношенню до тієї чи іншої життєвої ситуації, оцінює ії смисл і значення. Тому особливості життєвої ситуації $є$ важливим показником перетікання особистісного самовизначення.

За шкалою «Бадьорість-Сум, Смуток» (БО) результати тестування також в цілому знаходяться в межах тестової норми. Ця шкала несе важливу інформацію для розуміння особливостей протікання процесу особистісного самовизначення: iï показники, 3 одного боку, відображають бажання діяти i очікування радісних подій у майбутньому, а 3 іншого - зневіру і очікування загрозливих неприємностей.

За шкалою «Тонус» (ТО) високийнизький ситуація аналогічна. Ця шкала відо-

Таблиця 3

Результати статистичного аналізу даних за методикою визначення домінуючого стану (Л. В. Куліков)

\begin{tabular}{|c|c|c|c|}
\hline $\begin{array}{c}\text { Шкали } \\
\text { методики }\end{array}$ & Середнє & Станд. помилка & $\begin{array}{c}\text { Станд. } \\
\text { відхилення. }\end{array}$ \\
\hline АК & 32,94 & 0,50 & 8,16 \\
\hline БО & 24,19 & 0,38 & 6,22 \\
\hline ТО & 26,48 & 0,57 & 9,39 \\
\hline РА & 25,89 & 0,51 & 8,31 \\
\hline СП & 27,71 & 0,60 & 9,92 \\
\hline УС & 28,47 & 0,61 & 10,05 \\
\hline УД & 34,55 & 0,55 & 8,98 \\
\hline ПО & 23,70 & 0,40 & 6,57 \\
\hline
\end{tabular}

Умовні позначки шкал:

- АК - активне-пасивне ставлення до життєвої ситуації;

- БО - бадьорість - сум, смуток;

- ТО - тонус високий - низький;

- PA - розкутий - напружений;

- СП - спокій - тривога;

- УС - стійкість - нестійкість;

- УД - задоволеність - незадоволеність;

- ПО - позитивний - негативний образ самого себе. 
бражає готовність до реагування на виниклі труднощі і можливість витрачати енергію на таке реагування.

За результатами по шкалі «РозкутістьНапруженість» (РА) можна припустити, що досліджувані в цілому сприймають власні цілі як цілком досяжні. Питання тільки в тому, якими є такі цілі за змістом та реалістичністю.

За всіма шкалами тесту спостерігаються в середньому значення, що знаходяться в межах тестової норми. Але слід звернути увагу на показники стандартного відхилення, які вказують на наявність тенденції нерівномірності середніх показників за тестовими шкалами. Найбільший розкид індивідуальних показників досліджуваних має місце для шкали УС, що може вказувати на тенденцію щодо емоційної нестійкості певної частини досліджуваних. Це можна пояснити наявністю латентних екзистенціальних проблем як складової смисложиттєвих криз у певної частки досліджуваних.

Аналогічна картина спостерігається за шкалою СП. Так, індикатор шкали «СпокійТривога» (СП) сам по собі є також дуже важливим для розуміння особливостей протікання процесу особистісного самовизначення: 3 одного боку, він відображає ступінь впевненості в своїх силах і можливостях, а 3 іншого - очікування подій з несприятливим результатом, занепокоєння з приводу погроз різного походження. Можливо, певна частина досліджуваних саме це і переживає.
«Задоволеність-незадоволеність» (УД) життям в цілому, його ходом, процесом самореалізації, на наш погляд, - ключовий для розуміння і оцінки особливостей протікання процесу особистісного самовизначення. Досліджувані в цілому демонструють достатньо високий рівень задоволеності життям, але слід розрізняти два види такого задоволення: з одного боку - допроблемний, а фактично - інфантильний, який грунтується на психологічному захисті. 3 іншого - продуктивний, який виникає як наслідок успішного і продуктивного самовизначення. Співставлення результату за цією шкалою з результатами інших показників вказує на те, що більшість наших досліджуваних знаходиться на допроблемній стадії. Таким чином, процес особистісного самовизначення та, відповідно, і екзистенціальна рефлексія, ще не розгорнулися у наших досліджуваних повною мірою або носять спонтанний та епізодичний характер.

Шкала «Позитивний-негативний» образ самого себе (ПО) є допоміжною: вона дозволяє визначити критичність самооцінювання (низьке або високе) і його адекватність. Середні бали за цією шкалою знаходяться в межах тестової норми, а стандартне відхилення за цією шкалою є одним з найменших серед інших шкал. Це можна пояснити тим, що у досліджуваних виражена тенденція до адекватності в оцінці свого стану.

Критичність в оцінці себе тісно пов'язана з самоприйняттям особистості та $є$ важли- 
вою умовою успішності (продуктивності) особистісного самовизначення: чим повніше особистісне самовизначення, тим позитивніше образ себе, тим менше людина бачить в собі недоліків. Прийняття себе робить істотний вплив на настрій і психічний стан індивіда: чим повніше самоприйняття, чим більше в емоційному ставленні до себе позитивних почуттів, тим більше піднесено настрій, тим сприятливіший стан. Це підтверджують і виявлені нами кореляційні зв'язки при аналізі емпіричних даних. Дані зв'язку - двоспрямовані: чим більше піднесеним виявляється настрій, тим більш виражено прийняття себе, менше розбіжність між реальним і ідеальним Я особистості.

В Таблиці 4 представлено результати дослідження самоставлення.

Положення про взаємозв'язок особливостей самоставлення і особистісного самовизначення всебічно обгрунтовано в наших попередніх роботах, наприклад [6-8], причому як в теоретичному, так і в емпіричному планах. У контексті даного дослідження нас цікавить взаємозв'язок таких параметрів як характер самоставлення, глибина смисложиттєвої кризи i, відповідно, рівень (якість) екзистенціальної роботи особистості, структура семантичного простору як результат такої роботи і домінуючого психічного стану як фону, на якому і відбувається особистісне самовизначення.

Зупинимося на найбільш важливих особливостях самоставлення наших досліджува- них.

В цілому, результати, отримані за «Методикою дослідження самоставлення», корелюють 3 результатами інших методик цього дослідження, що є важливим аргументом на користь релевантності запропонованої концептуальної моделі та системи емпіричних індикаторів досліджуваної нами реальності.

Таблиця 4.

Результати статистичного аналізу даних за методикою дослідження самоставлення (С. Р. Пантилєєв)

\begin{tabular}{|c|c|c|c|}
\hline $\begin{array}{c}\text { Шкали } \\
\text { методики }\end{array}$ & Середнє & $\begin{array}{c}\text { Станд. по- } \\
\text { милка }\end{array}$ & $\begin{array}{c}\text { Станд. } \\
\text { відхилення. }\end{array}$ \\
\hline 3-О & 6,16 & 0,13 & 2,09 \\
\hline СУ & 9,50 & 0,18 & 2,89 \\
\hline СР & 7,14 & 0,13 & 2,10 \\
\hline ОС & 5,96 & 0,15 & 2,42 \\
\hline СЦ & 9,23 & 0,17 & 2,82 \\
\hline СП-е & 7,44 & 0,14 & 2,24 \\
\hline СП-р & 5,16 & 0,14 & 2,32 \\
\hline ВК & 6,80 & 0,21 & 3,51 \\
\hline СО & 4,87 & 0,16 & 2,55 \\
\hline
\end{tabular}

Умовні позначки шкал:

- 3 - замкнутість (закритість);

- СУ - самовпевненість;

- СP - самокерівниитво;

- ОС - відображене самоставлення;

- СЦ - самоиінність;

- СП-е - самоприйняттяя;

- СП-р - самоприхильність;

- ВК - внутрішня конфліктність;

- СО - самозвинувачення.

В цілому, наші досліджувані демонструють незначний рівень внутрішньої чесності або усвідомленості Я (рефлексивності Я за М. Розенбергом). Це може означати, що в ці- 
лому рефлексивні процеси у них ще не запущені в належній мірі, а їхнє Я ще не стало предметом осмислення і переосмислення.

Парадоксально, але середній показник за шкалою «Самовпевненість» (СУ), навпаки, вище за тестову норму В цілому досліджувані відносяться до себе як до впевнених, самостійних і надійних людей, яким є за що себе поважати. Залишається відкрите питання: на чому будується така самовпевненість? Враховуючи результати психосемантики, можна припустити, що, скоріше за все, це - результат поки що більш-менш успішного самоствердження, а не самовизначення.

Показники за шкалою «Самоцінність» (СЦ) в цілому по вибірці статистично достовірно вищі тестової норми. Аналогічна картина спостерігається i за шкалою «Самоприйняття» (СП-е).

Достатньо показовий і симптоматичний результат отримано за шкалою «Самоприхильність» (СП-р): високі бали за цими шкалами можуть спостерігатися у тих, хто має більш адекватний «Я»-образ, більш позитивне ставлення і менш консервативну прихильність до цього образу. Фактично, це показник більш високого рівня розвитку особистісної рефлексії.

На основі отриманих даних можна зробити припущення, що в цілому рівень розвитку або сформованості особистісної рефлексії а також і екзистенціальної рефлексії статистично значимо нижчий за тестову норму. Це - ще один доказ стосовно консервативної прихильності більшості досліджуваних до власного Яобразу. Аргументом до цього також є середній показник за шкалою «Внутрішня конфліктність» (ВК) - він суттєво нижчий за тестову норму, що може вказувати на неактуальність для більшості наших досліджуваних осмислення і переосмислення свого власного досвіду. Аналогічна картина спостерігається i за шкалою «Самозвинувачення» (CO).

Таким чином, можна зробити наступне узагальнення: для більшості досліджуваних $є$ неактуальним процес як пошуку себе (процес самовизначення), так і формування результату цього процесу, а саме - готовності до самореалізації. На фоні цих процесів екзистенціальна робота особистості та її складова - екзистенціальна рефлексія - в цілому має спонтанний та латентний характер.

\section{Висновки 3 проведеного дослідження.}

Процес особистісного самовизначення як осмислення i переосмислення особистістю ступеня своєї готовності до самореалізації, супроводжується екзистенціальною роботою особистості, яка має переживальний та рефлексивний аспекти. Власно особистісне самовизначення починається 3 того, що смисл життя як узагальнений мотив життєдіяльності перестає виконувати свою спонукальну, спрямовуючу і смислоутворюючу функцію. Завершується процес успішного особистісного самовизначення формуванням нового чинного узага- 
льненого мотиву життєдіяльності або смислу життя. Саме особистісне самовизначення $€$ тим психологічним феноменом, в рамках і в контексті якого найбільш перспективно і продуктивно вивчати екзистенціальну рефлексію, особливо в емпіричному плані.

Концептуальна модель екзистенціальної рефлексії і система індикаторів для іiї емпіричної верифікації викладена в наступних твердженнях.

1. Найбільш цілісну картину результатів роботи екзистенціальної рефлексії відображає семантичний простір, який містить екзистенції і маркери, що характеризують особливості особистісного самовизначення та самореалізації досліджуваних. Місце і роль продуктів (результатів) роботи екзистенціальної рефлексії у структурі та змісті готовності до самореалізації оцінювалися нами за допомогою методики «Психосемантична діагностика прихованої мотивації» (І. Л. Соломін).

2. Особливості самоставлення - найбільш цілісний і інформативний показник успішності протікання процесу особистісного самовизначення, результатом якого $є$ формування готовності до самореалізації. Готовність до самореалізації - це, в першу чергу, чітко виражений позитивний особистісний смисл «Я», сформованість якого і відображається в особливостях самоставлення. Власне самореалізація спрямована на підтвердження і втілення цього смислу в діяльності і в реалізації життєвих ставлень, послідовно обгрунтовуєть- ся в наших роботах. Цей показник оцінюється нами за «Методикою дослідження самоставлення» (С. Р. Пантелєєв).

3. Екзистенціальна робота - це реакція особистості на виникнення смисложиттєвої кризи. Саме екзистенціальна робота - необхідна умова і один з основних факторів вирішення такої кризи. Чим глибше смисложиттєва криза, тим більш інтенсивною і розгорнутою $є$ екзистенціальна робота особистості, що протікає як в переживальній, так і в рефлексивній формах. Оцінити особливості цієї кризи дозволяє спеціальний «Опитувальник смисложиттєвої кризи» (К. В. Карпінський).

\section{4. Смисложиттєва криза - триваючий} психічний стан, який виникає на основі ще неусвідомлених або нерозв'язаних суперечностей у пошуку та практичній реалізації особистістю смислу індивідуального життя. При цьому особистість відчуває цілий комплекс негативних почуттів: незадоволеності, невиконання, апатії, неспроможності, фрустрації і т. д. «Методика визначення домінуючого стану (повний варіант, Л. В. Куликов)» визначає характеристики настроїв і деякі характеристики особистісного рівня психічних станів за допомогою суб'єктивних оцінок досліджуваного. Опитувальник призначений, головним чином, для діагностики відносно стійких (домінуючих) станів. Крім того, ця методика включає в себе важливі емпіричні індикатори, які прямо або побічно відображають хід процесу особистісного самовизначення, а голов- 
не - продукти цього процесу.

Діагностичні конструкти вказаних вище методичних засобів в достатньому ступені перетинаються, що є обгрунтуванням релевантності запропонованої нами концептуальної моделі екзистенціальної рефлексії. Емпіричні дослідження, проведені нами, показують значиму кореляцію між шкалами і субшкалами використаних нами методик.

Перспективи подальших досліджень. Подальший розвиток запропонованої нами концептуальної моделі екзистенціальної рефлексії та її емпіричне обгрунтування передбачає проведення серії формуючих експериментів. Наша логіка проста.

1. Якщо ми достатньо глибоко розуміємо сутність екзистенціальної рефлексії, знаємо iii основні властивості, то це означає, що зможемо актуалізувати і культивувати екзистенціальну роботу особистості в так званих лабораторних або спеціально створених умовах. Одним 3 можливих варіантів таких спеціально створених умов $\epsilon$, наприклад, психологічний тренінг.

2. За допомогою спеціальних процедур і технік в умовах тренінгу можливо забезпечити актуалізацію і необхідну інтенсивність екзистенціальної роботи його учасників.

3. За допомогою діагностичного інструментарію, що застосовувався нами при проведенні констатуючої серії емпіричних досліджень, стає можливим фіксація «ефекту тренінгу», тобто зміни в смисловій сфері досліджу- ваних до та після тренінгу.

Нами була розроблена і успішно апробована в навчальному процесі психологопедагогічна система, спрямована на роботу 3 екзистенціальним досвідом студентів - тренінг-практикум «Екзистенціальний досвід усвідомленості і осмислення», орієнтований на студентів 2-3 курсів вищих навчальних закладів, для яких питання особистісного та професійного становлення $є$ найбільш актуальними. Мета тренінгу-практикуму - актуалізація, осмислення і переосмислення екзистенціального досвіду в аспекті особистісного самовизначення [9].

Також нами був верифікований «ефект тренінгу», що, перш за все, підтверджує конструктну валідність нашої моделі [10].

Вже проведені нами в цьому ключі дослідження поки що носять попередній характер. Отримані результати вимагають подальшого теоретичного та емпіричного обгрунтування.

\section{Перелік використаних джерел:}

1. Двоеглазова М. Ю. Развитие личностной рефлексии в студенческом возрасте / М.Ю. Двоеглазова, И.Н. Семенов. - Мурманск: МГПУ, 2007. - 188 с.

2. Карпинский $K$. B. Взаимосвязь самоотношения и смысложизненного кризиса в развитии личности / К.В. Карпинский // Мир психологии. - 2010. - №4 (64). - С. 152-167.

3. Карпинский К. В. Опросник смысложизненного кризиса: монография / К.В. Карпинский. - Гродно: ГрГУ, 2008. - 108 c. 
4. Куликов Л. В. Руководство к методикам диагностики психических состояний, чувств и психологической устойчивости личности. Описание методик, инструкции по применению / Л.В. Куликов. - СПб., 2003. - 81 c.

5. Пантилеев С. Р. Методика исследования самоотношения / С.Р. Пантилеев. - М.,1993. - 32c .

6. Репецкая $A$. В. Рефлексивно-личностное самоопределение как формирование готовности к самореализации / А.В. Репецкая, Ю.А. Репецкий // Психология. Журнал ВШЭ. - 2013. - Спецвыпуск по рефлексивной психологии. - С. 53-67.

7. Репецикая $A$. В. Экзистенциальная рефлексия и изменение восприятия личностью себя и своего жизненного мира / А.В. Репецкая, Ю.А. Репецкий // Мир психологии. - 2013. - №1(73). - С. 148-154.

8. Репецька А. В. Дослідження особливостей особистісного самовизначення студентів психосемантичними методами / Репецька А.В., Репецький Ю.А. // Проблеми емпіричних досліджень у психології. - Вип. №7. - 2013. - C. 195-204.

9. Репецька A. B. Методичні вказівки до проведення практичних занять у формі тренінгу з формування екзистенціального досвіду усвідомленості та осмислення у студентів-психологів усіх форм навчання (для викладачів психологічних дисциплін) / автор-укл.: А.В. Репецька. - Запоріжжя: ЗНТУ, 2017. - 62 с.

10. Репецька A. В. Робота з екзистенціальним досвідом студентів ВНЗ: теорія, практика, верифікація /А.В. Репецька / Психологічні основи розвитку особистості : монографія / за заг. ред. В.Й. Бочелюка, за ред. М.А. Дергач, Н.В. Волошиної. - Запоріжжя: Просвіта, 2017. - C. 122-150.

11. Семенов И. Н. Проблемы рефлексивной психологии решения творческих задач / И.Н. Семенов. - М., 1990. 479 c.

12. Соломин И. Л. Психосемантическая диагностика мотивации. Методическое руководство. - СанктПетербург, 2013. - 60 с.

\section{References (Transsliteration):}

1. Dvoyeglazova $M$. YU. Razvitiye lichnostnoy refleksii v studencheskikh vozraste / M.YU. Dvoyeglazova, I.N. Semenov. - Murmansk: MGPU, 2007. - 188 s.

2. Karpinskiy $K$. V. Vzaimosvyaz' samootnosheniya i smyslozhiznennogo krizisa $\mathrm{v}$ razvitii lichnosti / K.V. Karpinskiy // Mir psikhologii. - 2010. - №4 (64). - S. 152-167.

3. Karpinskiy $K$. $V$. Oprosnik smyslozhiznennogo krizisa: monografiya / K.V. Karpinskiy. - Grodno: GrGU, 2008. $108 \mathrm{~s}$.

4. Kulikov L. V. Rukovodstvo $\mathrm{k}$ metodikam diagnostiki psikhicheskikh sostoyaniy, chuvstv i psikhologicheskoy ustoychivosti lichnosti. Opisaniye metodik, instruktsii po primeneniyu / L.V. Kulikov. - SPb., 2003. - 81 s.

5. Pantileyev $S$. R. Metodika issledovaniya samootnosheniya / S.R. Pantileyev. - M., 1993. - 32s.

6. Repetskaya A. $V$. Refleksivno-lichnostnoye samoopredeleniye kak formirovaniye gotovnosti k samorealizatsii / A.V. Repetskaya, YU.A. Repetskiy // Psikhologiya. Zhurnal VSHE. - 2013. - Spetsvypusk po refleksivnoy psikhologii. - S. 53-67.

7. Repetskaya A. V. Ekzistentsial'naya refleksiya i izmeneniye vospriyatiya lichnost'yu sebya i svoyego zhiznennogo mira / A.V. Repetskaya, YU.A. Repetskiy // Mir psikhologii. - 2013. - №1 (73). - S. 148-154.

8. Repetskaya $A$. $V$. Issledovaniye osobennostey lichnostnogo samoopredeleniya studentov psikhosemanticheskimi metodami / Repetskaya A.V., Repetskiy YU.A. // Problemy empiricheskikh issledovaniy $\mathrm{V}$ psikhologii. Vyp. №7. - 2013. - S. 195-204.

9. Repetskaya A. V. Metodicheskiye ukazaniya k provedeni$\mathrm{yu}$ prakticheskikh zanyatiy $\mathrm{v}$ forme treninga po formirovaniyu ekzistentsial'nogo opyta osoznannosti i osmysleniya studentov-psikhologov vsekh form obucheniya (dlya prepodavateley psikhologicheskikh distsiplin) / avtor-sost.: A.V. Repetskaya. - Zaporozh'ye: ZNTU, 2017. - 62 s.

10. Repetskaya $A$. $V$. Rabota s ekzistentsial'nym opytom studentov vuzov: teoriya, praktika, verifikatsiya /A.V. 
Repetskaya / Psikhologicheskiye osnovy razvitiya lichnosti: monografiya / Pod obshch. red. V.I. Bochelyuka, pod red. M.A. Dergach, N. Voloshinoy. - Zaporozh'ye: Prosvita, 2017. - S. 122-150.

11. Semenov I. N. Problemy refleksivnoy psikhologii resheniya tvorcheskikh zadach / I.N. Semenov. - M., 1990. 479 s.

12. Solomin I. L. Psikhosemanticheskaya diagnostika motivatsii. Metodicheskoye rukovodstvo. - Sankt-Peterburg, 2013. $-60 \mathrm{~s}$

\section{Repetska Anzhela}

Senior lecturer, National Technical University of Zaporizhzhia, Zaporizhzhia (Ukraine)

\section{EXISTENTIAL REFLECTION AS DIAGNOSTIC CONSTRUCTION: VERIFICATION OF MAIN PROPERTIES}

\section{ABSTRACT}

The object of our research is the personal self-determination of students.

The subject of the study is existential reflection.

The aim of the research is to empirically substantiate the conceptual model of existential reflection, to reveal its place and role in the process of personal self-determination. Existential reflection is the mechanism of structuring and transforming the existential experience of the individual. Existential reflection plays an important role in the work of the mechanism of existential sense formation and semantic dynamics.

Existential experience is the object of existential reflection. In the structure of existential experience there are three sources of meaning and three mechanisms of sense formation function, respectively: 1) the motive mechanism is based on the meaning of life; 2) the basis of the dispositional mechanism is the self-relation of the individual; 3) the basis of the attributive mechanism is the - I-concept as a set of qualities and characteristics of the individual. The contribution of each source was studied by us with the help of using the corresponding adequate psychodiagnostic techniques:

1. Psychosemantic diagnosis of latent motivation (I. L Solomin).

2. Methods of investigating the selfrelationship (S. R Pantileev).

3. Questionnaire of the meaningful crisis (K. V Karpinsky).

4. Methods for determining the dominant state condition (full version, L. V. Kulikov).

In the course of During the empirical verification of the conceptual model of existential reflection, 271 students of different universities, different specialties and courses aged from 17 to 22 years were diagnosed. The result of the existential-reflexive work was evaluated through the features of the structure of existential experience, represented by a semantic space of 15 basic concepts - markers of existences.

According to the results of the research, it was revealed that for most of the subjects the process of finding oneself (the process of selfdetermination) and shaping constructing the result of this process - the readiness for self-realization is not actual for the most of represenatives. Against the backdrop of these processes, the exis- 
tential work of the individual and its component existential reflexion - on the whole is has spontaneous and latent in nature generally.

Our main thesis: existential sense formation, sense-awareness and meaning-building play a key role in the process of personal selfdetermination.

Key words: personal self-determination, existential work of the individual, existential reflection, existential experience, meaning of life, self-relation, empirical verification, psychosemantic space.

\section{Репецкая Анжела Васильевна}

Старший преподаватель кафедры психологии Запорожского национального технического университета, 2. Запорожье (Украина)

\section{ЭКЗИСТЕНЦИАЛЬНАЯ РЕФЛЕКСИЯ КАК ДИАГНОСТИЧЕСКИЙ КОНСТРУКТ: ВЕРИФИКАЦИЯ ОСНОВНЫХ ПОЛОЖЕНИЙ}

Аннотация. Объект нашего исследования - личностное самоопределение студентов.

Предмет исследования - экзистенциальная рефлексия.

Цель исследования - эмпирически обосновать концептуальную модель экзистенциальной рефлексии, выявить ее место и роль в процессе личностного самоопределения. Экзистенциальная рефлексия - это механизм структурирования и трансформации экзистенциального опыта личности. Экзистенциальная рефлексия играет важную роль в работе механизма экзистенциального смыслообразования и смысловой динамики.

Объектом экзистенциальной рефлексии является экзистенциальный опыт. В структуре экзистенциального опыта есть три источника смысла и функционирует, соответственно, три механизма смыслообразования: 1) в основе мотивационного механизма лежит смысл жизни; 2) в основе диспозиционного механизма самоотношение личности; 3) в основе атрибутивного механизма - Я-концепция как совокупность качеств и особенностей личности. Вклад каждого источника изучался нами с помощью соответствующих психодиагностических методик:

1. Психосемантическая диагностика скрытой мотивации (И. Л. Соломин).

2. Методика исследования самоотношения (С. Р. Пантилеев).

3. Опросник смысложизненного кризиса (К. В. Карпинский).

4. Методика определения доминирующего состояния (полный вариант, Л. В. Куликов).

В ходе эмпирической верификации концептуальной модели экзистенциальной рефлексии было продиагностировано 271 студента разных вузов, разных специальностей и курсов в возрасте от 17 до 22 лет. Результат экзистенциально-рефлексивной работы оценивался через особенности структуры экзистенциального опыта, представленной семантическим пространством из 15 базовых понятий маркеров экзистенций. 
По результатам исследования было выявлено, что для большинства испытуемых неактуален процесс поиска себя (процесс самоопределения) и формирование результата этого процесса - готовности к самореализации. На фоне этих процессов экзистенциальная работа личности и ее составляющая - экзистенциальная рефлексия - в целом имеет спонтанный и латентный характер.

Наш основной тезис: экзистенциальные смыслообразование, смыслоосознание и смыслостроительство играют ключевую роль в процессе личностного самоопределения.

Ключевые слова: личностное самоопределение, экзистенциальная работа личности, экзистенциальная рефлексия, экзистенциальный опыт, смысл жизни, самоотношение, эмпирическая верификация, психосемантическое пространство. 